April 2020, VOLUME 8, ISSUE 2, 32-43

E-ISSN NO: $2289-4489$

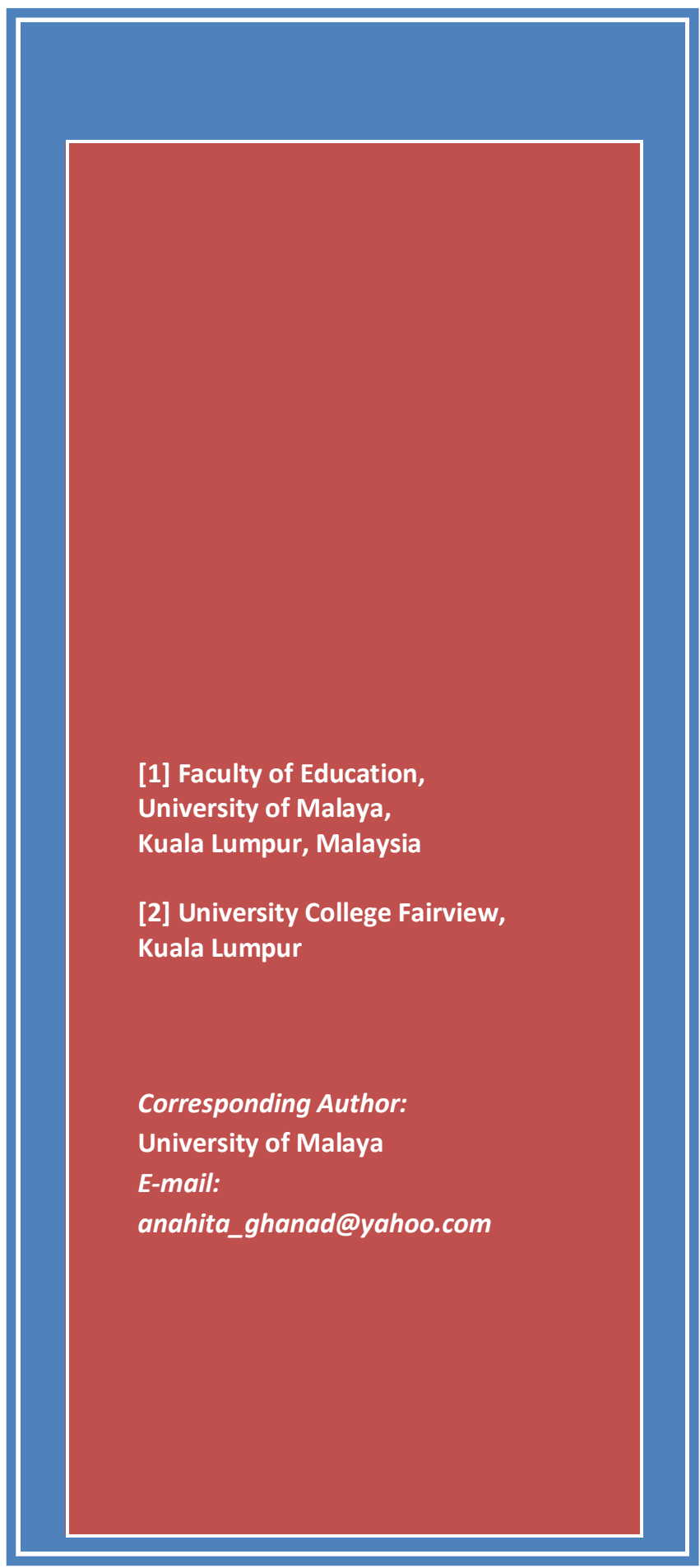

\section{AN ANALYSIS OF THE ORGANIZATIONAL CULTURE OF PREMIER UNIVERSITIES IN MALAYSIA}

Anahita Ghanad ${ }^{1}$, Sufean Hussin $(\mathrm{PhD})^{2}$ \& Dorothy DeWitt $(\mathrm{PhD})^{1}$

\begin{abstract}
An empirical research was done to examine and analyze the crucial domains in the organizational culture of world-ranked or premier universities in Malaysia, particularly in terms of their core values, direction, management effectiveness, innovation, customer focus, and institutional policies. The research employed a survey instrument on organizational culture and involved 1440 university students who were randomly selected from different faculties at four premier universities in the vicinity of Kuala Lumpur region in Malaysia. As highlights of this paper, the research found that the crucial cultural domains of premier universities were institutional policies, empowerment issue, team orientation behavior, and capability development of students. It was also found that students in premier public universities were more satisfied with their campus culture than students in premier private universities. Besides that, the important institutional policies were equality, academic integrity, and multiculturalism. Consequently, in terms of significance, new colleges and universities in Malaysia or other countries, whether public or private, may use the results and findings of this research for upgrading their organizational culture in order to achieve global ranking in the future.
\end{abstract}

Keywords: Higher Education, University Organization, University Types, Organizational Culture Model, Open System Theory 


\section{MALAYSIAN ONLINE JOURNAL OF EDUCATIONAL MANAGEMENT (MOJEM)}

\section{INTRODUCTION}

This paper begins with the conceptualization of culture. A notable scholar, Schein (2004) states that culture is the way of life of a community in which there is a pattern of tradition, ideas, attitudes, rituals, and practices that is unique only to that community. The uniqueness can be attributed to shared assumptions, beliefs, expectations, ethos, roles, and norms among members of a community, and those elements become embedded in the unconscious psyche and intellect, which are consecutively reflected and reinforced by values, artefacts, rules, practices, and behaviors. Schein also posits that culture is a body of knowledge in the community that has been accumulated for many generations and become relevant and useful for addressing conflicts, issues and problems affecting a community, and in the passage of time that knowledge becomes propounded as principles or codes of communityhood. On the other hand, scholars such as Hofstede and Hofstede (2001) simplify the definition of culture as fundamentally about how people conduct their life, what people think about living as a community, what people believe about the world around them, and how people interact among each other in their community. Tradition and norms are embedded in beliefs and values; hence, culture becomes the reference framework for people to organize their daily life, for them to use in decision-making and deriving solutions, and for them to transmit it to their members. This definition aptly applies to the university organization, which has its own unique culture within the context of the larger society.

In the context of this study, universities are defined as higher education institutions which provide specialized or professional education and training of youth in different disciplines and areas of study which prepare them for employment in the job market, career, or vocation (Hussin \& Wong, 2011). Simultaneously, universities are also corporate organizations because of the fact that they function as a business entity which employs different categories and levels of employees to perform different kinds of jobs and duties based on a certain set of goals, structure, and work process (Asimiran \& Hussin, 2012; Ismail, 2008; Sporn, 1996). In this regard, universities are complex corporate organizations which have their own peculiar culture, priorities, roles, expectations, and rules (Tama, 2019; Wang, 2016). Asimiran (2009) asserts that as a corporation, a university has its own organizational structure comprising intricate connections and networking among its constituent faculties, institutes, academies, departments, and units that construct the whole university organization. The organization structure also delineates the lines of power, authority, roles, and communication among its constituents and also portrays the web in the management hierarchy and processes among faculties and departments (Asimiran \& Hussin, 2012). Consequently, the academic and management staff as well as students in the campus community are bound by the policies, rules, and regulations that govern the entire academic institution. There is always the dichotomy of functions: the Senate deliberate and make decisions on academic matters, while the management are accountable for operational and development affairs, based on the so-called tradition and concepts of autonomy and empowerment in higher education institution (Hussin \& Wong, 2015; Asimiran, 2009).

In terms of constituency, Wang (2016) conceptualizes that a campus culture is the integral composition of the subcultures at faculties, institutes, and departments which are diversified and different from each other in terms of their roles and values. For example, the sub-culture at a science or medical faculty is different from that at a liberal arts faculty. From another perspective, at the structural level, universities are unique communities or organizations, unlike business and bureaucratic organizations, because they comprise faculties, departments, and disciplines that are autonomous in their academic and research pursuits. However, in their specific uniqueness, at the stakeholder level, university governance and culture can be categorized and shaped by their nature or model of establishment: oligarchy of scholars, total state-controlled, partial state-controlled, and corporation (Gornitzka \& Maasen, 1998; Gornitzka, \& Peter, 2000; Wright, 2019).

In our research, the conceptual model and survey instrument developed by Denison (1990) was used as it is the most relevant and suitable because the model has a sound theoretical construct and it has been used before in many empirical studies on the organizational culture of business corporations. And, it was also because the model could be employed as a quantitative tool for a systematic and logical analysis of the components and domains of 


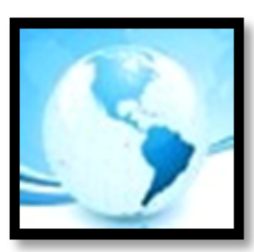

\section{MALAYSIAN ONLINE JOURNAL OF EDUCATIONAL MANAGEMENT (MOJEM)}

university organizational culture. Denison's model has been the theoretical foundation for the development of the survey instrument which we used in our research which analyzes the components and domains of university corporate organization.

Theoretically, Denison's (1990) cultural model is associated with the open system theory which asserts that a living system such as a university is constantly shaped by the forces of activisms, knowledge expansion, innovations, trends, and developments outside and inside the campus environment (Weber \& Waeger, 2017). As a learning organization, the university then reacts by making adaptations and changes in tandem with momentum and tempo of the interaction between external and internal forces, for achieving the goals of being competitive, efficient, and sustainable (Senge, 1990). The adaptations and changes in a university can be seen in terms of administrative policies, organizational structure, financial allocations, research grants, quality assurance process, and student affairs. Oftentimes, in tandem with those trends and demands, the university community and its culture also changes gradually and implicitly in terms of people's beliefs, values, attitudes, and practices (Gibson \& Barsade, 2003).

\section{PROBLEM STATEMENT}

Many research works have been done on the organizational culture of business corporations, but there is a scarcity of empirical research done on university organizations. Here lies the research gap or the problem area, and there are two reasons for this issue: (i) business corporations support and fund research works on culture for the purpose of competitive advantage and change; (ii) the complexity of university organization structure is due to the diversity of sub-cultures at faculties, institutes, disciplines and fields of studies, all of which can be very problematic and a hindrance in a systematic research (Gaus, Tang, \& Akil, 2017). The diversity of faculties, research orientations, curricula, roles, values, and ideas can lead to the complexity of research methodology, results, and conclusions. Specifically, at the organizational level, the main problem or burning question so far that needs to be answered by previous research is: as an organization, what are the components and domains of the university culture that makes it unique from the culture of business corporations? There have been sporadic case studies in the past few years, but they are not reliable and inconclusive in their findings and propositions.

\section{LITERATURE REVIEW}

Ideas about university culture have not been definite and consistent because of different conceptions and research methodologies involved. Quantitative researchers did not concur with qualitative researchers in terms of the basic constructs and dimensions of university culture. Quantitative researchers had largely relied on categorical models, whereas qualitative researchers had relied on the anthropological method or case study method in studying culture. With regard to this epistemological divide, however, our research adopted the quantitative approach via the use of a survey instrument which was constructed based on the identification of the most relevant conceptual model and the operationalization of concepts or constructs involved.

From the literature, we can identify three cultural theories concerning organizations, including schools and universities. First, Schein's (1985) cultural theory postulates that a culture consists of a body of inherent assumptions and beliefs which are portrayed in the norms and practices of people in a community. In the case of a university, the assumptions and beliefs can be seen in the university constitution and statutes, which are then manifested in governance policies, administrative rules and regulations, and campus environment and facilities. Norms and practices can be seen in the roles, attitudes, behaviors, and activities of the employees in the organizational structure as well as students who constitute the customers and learners in a university.

The second theory is by Denison (1990) who postulates that there is an interplay of external forces and internal forces affecting an organization and thus the scope of organizational culture can be examined in four distinct components: implementation of mission and vision; consistency of values and actions; active involvement or 


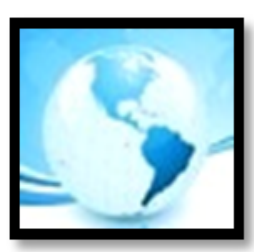

\section{MALAYSIAN ONLINE JOURNAL OF EDUCATIONAL MANAGEMENT (MOJEM)}

participation of people in a community; and adaptability to demands and changes that come from inside and outside of the community. And the third theory is by McNay (1995) who postulates a two-dimensional model of organizational culture, that is, on one dimension is form and intensity of control, and the other dimension is on focus of strategic policies and actions. The crossing of the two dimensions yields four quadrants, each describing a particular type of culture. The four types of organizational culture are enterprise, corporate, collegiate, and bureaucratic. Jameson (2011) made an important contribution in the study of organization culture by metaanalyzing studies that were done using McNay's model. Jameson consequently constructed a matrix table to explicate specific differences and salient characteristics of the four types of organizational culture. Among the salient cultural characteristics examined and identified were dominant values, management style, management roles, decision areas, and nature of change. Arising from McNay's model is the Competing Values Framework (CVF) that has triggered many survey studies in past three decades since the 1990's (Beytekin, Yalçinkaya, Doğan, \& Karakoç, 2010). As an important note, among the three theories discussed, Denison's theoretical model was used in our research to explicate in specific details about the organizational culture of premier or world-ranked universities involved in our research.

There was a fervent interest among researchers in the 1990's to study organizational culture, as if there was a new intellectual movement in the social sciences. For example, from a few studies, Sporn (1996) puts forth in a paper a few important points that managers should be aware of in managing university culture: goals are ambivalent due to ambiguous decision-making process; universities are people-oriented institutions that are complicated by a lot of issues and agendas; academics are experts who have the authority in determining the curricula; problematic standards in goal attainment. This implies the difficult constructs or concepts involved in examining university culture. Going along Schein's (2004) conception, university culture is largely guided and driven by the core values in its vision and mission statements. For example, Ozdem (2011) made a meta-analysis of vison and mission statements of 72 universities in Turkey, and he found that the predominant core values were provision of high quality education and training of graduates by highly qualified staff; provision of high quality services and facilities; responsibility to community development and services; and becoming a leading institution in research and development. Academic integrity and institutional reputation were part of high quality education and training.

In a qualitative research, Kramer and Berman (2009) examined stories written by students regarding cultural elements of their university such as the architecture of buildings, campus landscape, facilities, and policies that they could observe and comprehend, including the common beliefs, values, norms, stereotypes, prejudices, rituals, and behaviors in their campus. The findings of their study suggested that campus culture comprises many subcultures that have conflicting values, goals, and interests. The student sub-culture was frequently in conflict with the status quo tradition and values set and followed by the university establishment. Students frequently posed challenges in order to change and reform inhibitive or rigid policies and rules. Overall, students' stories demonstrated their sense of belonging, sentiments on events around them, and could play a beneficial input in making changes in academic and management affairs.

Köse and Korkmaz (2019) conducted a quantitative study for the purpose of categorizing types of university culture in general, i.e. not into the specific aspects and characteristics of organizational culture. Results of their study showed that university culture in Turkey could be categorized into three main types such as innovative team culture, competitive culture, and hierarchical culture. If job performance of academics was taken into account as the dependent variable, then there were significant relationships between job performance and competitive culture and innovative team culture respectively. By regression analysis, interestingly it was found that competitive culture is the determinant factor or predictor of job performance among academics in Turkish universities.

In Germany, a research by Yacizi and Karabag (2019) used Jameson's (2011) typology and examined organizational culture and learning organization via a survey study. They found that German universities had hierarchical culture which was efficient for the purpose of dealing with complexity and diversity of roles and functions that were largely based on standard policies and rules. The salient cultural features of German universities were strategic 


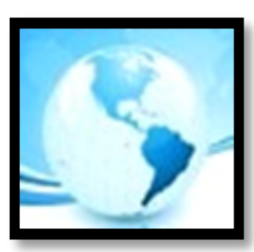

\section{MALAYSIAN ONLINE JOURNAL OF EDUCATIONAL MANAGEMENT (MOJEM)}

emphasis, dominant characteristics, organizational leadership, employee management, organizational coherence, and success criteria. Synthesizing their research findings, Yacizi and Karabag develop a conceptual framework of the organizational culture of German universities, incorporating Schein's (1985) cultural conception as well.

\section{RESEARCH METHODOLOGY}

The objectives of our research were to examine the crucial domains in the culture of premier universities and consecutively to determine the significant cultural differences between premier public and private institutions in Malaysia. "Premier" here means among the top-500 in the QS Global Ranking of Universities in 2017. The research questions of the study were as follows:

1. In general, what are the crucial domains and salient characteristics of some premier universities in Malaysia?

2. Are there significant cultural differences between the premier public and private universities?

To answer those questions, we collected quantitative data using Denison's survey instrument (Denison, 2020) called the OCDI (Organizational Culture Diagnostic Instrument). Theoretically and conceptually, the instrument was based on Denison's model (Denison, 1990), which propounded that the interplay between external forces and internal forces determines the nature of organizational culture of corporations, including the universities. The external forces could affect the mission and consistency components of university organizational culture, whereas the internal forces could shape the involvement and adaptability components. Specifically, each of the four components comprised a few cultural domains, which could be elaborated categorically as follows:

- Mission component of a university comprises domains such as university vision, its strategic goals and objectives, and the plan for strategic actions.

- Consistency component consists of domains such as university core values, coordinated agreement on decisions among faculties, and integration of management process.

- Involvement component consists of domains such as empowerment in making decisions, teamwork orientation, and development priorities.

- Adaptability component consists of domains regarding making necessary changes and innovations, attention to customers' needs, and campus facilities and settings.

Each domain consisted of five survey items, each with an ordinal scale corresponding with responses of 1 to 5 (response 1 for "totally disagree" to response 5 for "totally agree") in the response column of questionnairetypical of a survey instrument. In total there were 12 domains and 60 items in the original OCDI, but to suit the university context, we added an extra domain, that is, important policies on university reputation-taking into consideration world-ranking and internationalization. Thus our OCDI version had 13 domains and 65 items altogether.

Then after, a pilot study was conducted at one university - not involved in the study - to check the reliability of the adjusted OCDI, and from data analysis, it was found that the Cronbach alpha values of items and domains to be in range of 0.65 to 0.96 , which indicated that the OCDI had high reliability (Creswell, 2012). Also determined was the construct validity of the OCDI by using the principal component analysis (PCA), a statistics which extracted the maximum variance of variables or domains in the OCDI (George \& Mallery, 2016) -this kind of analysis is rarely done in most survey research. The PCA analysis produced results for all domains in the range of 0.622 to 0.835 , i.e. high validity of OCDI.

For the actual study, only the top four premier or world-ranked universities in Malaysia were purposively selected from the list in the QS Global Ranking of Universities, 2017. Only the top- two public universities and top-two private universities were purposively selected for this study. As for the sample, the required number of 


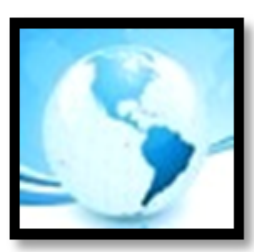

\section{MALAYSIAN ONLINE JOURNAL OF EDUCATIONAL MANAGEMENT (MOJEM)}

respondents for the study was determined by using Krejcie and Morgan (1970) table of random sample, which indicated that the suitable number to be in the range of 330 to 360 respondents per university. The four premier universities had different number of faculties and student population. Subsequently, the organizational culture survey questionnaire was distributed randomly to 1520 university students, undergraduates and graduates, from numerous faculties that were also chosen at random. Data collection was slow, but after three months a total of 1440 fully-answered survey questionnaires were successfully collected. Data were then entered into and statistically analyzed by the computer program IBM SPSS Statistics Version 23 (George \& Mallery, 2016).

\section{RESULTS AND FINDINGS}

Data from the 1440 survey questionnaires was computed and statistically analyzed. As a prerequisite procedure, a normality test was performed on the survey data, and it was found that the data had a normal distribution or normality (Hair, Black, Babin, \& Anderson, 2006). This procedure was compulsory before performing inferential statistics such as analysis of variance (Anova), independent samples test, and multiple regression.

As for research question 1, regarding the crucial cultural domains of premier universities, the results of data analysis are as shown in the following Table 1.

Table 1

Mean and rank position of cultural domains in premier universities

\begin{tabular}{lccc}
\hline \multicolumn{1}{c}{ Domain of University Organization Culture } & Mean & Sd & Rank \\
\hline Vision and Mission & 3.672 & 0.961 & 7 \\
Goal and Objectives to be achieved & 3.643 & 0.833 & 9 \\
Strategic direction and intent of management & 3.626 & 0.931 & 10 \\
Core values of university & 3.685 & 0.924 & 5 \\
Agreement in policies and decisions & 3.591 & 0.896 & 11 \\
Coordination/ integration in management & 3.552 & 0.782 & 12 \\
Empowerment in decisions and programs & 3.753 & 0.916 & 3 \\
Team orientation in organization & 3.798 & 0.872 & 2 \\
Capability enhancement of members & 3.726 & 0.866 & 4 \\
Making innovations and changes & 3.657 & 0.957 & 8 \\
Customer focus & 3.534 & 0.934 & 13 \\
Organizational learning policy & 3.692 & 0.781 & 6 \\
Important university policies/ Reputation & 3.861 & 0.962 & 1 \\
\hline
\end{tabular}

Note: $\mathrm{Sd}$ is standard deviation, $\mathrm{N}=1440$

By looking at the rank column in Table 1, it could be seen that the important cultural domains of the examined premier universities were important university policies regarding reputation (rank 1); team orientation of staff and students as guided by vision and mission (rank 2); staff empowerment in management and academic matters (rank 3); enhancement of job capability for staff and students in implementing change and innovation (rank 4); and adherence to the core values espoused by the university community that form the conscience of its members (rank 5). In this regard, the respondents realized and upheld the important university policies, particularly regarding multiculturalism, academic integrity, and plagiarism which affect university reputation internationally. Apart from that, students perceived that teamwork orientation was an important concept in their university culture.

On the contrary, however, the lowest-ranked domains in Table 1 were customer focus (rank 13), co-ordination and integration among faculties and departments (rank 12), and agreement among faculties in decision-making process (rank 11). In other words, students perceived those cultural domains do exist in universities. We expected that the 


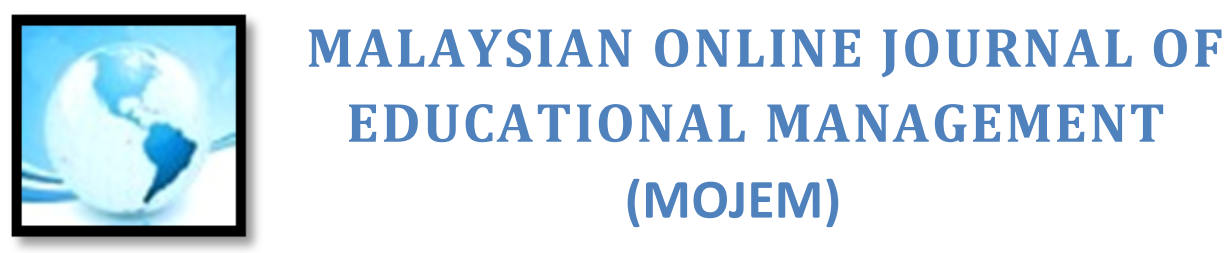

vision and mission domain as well as the strategic direction domain to have a mean value higher than 4.0, but they were ranked 7 and 10 respectively. The main reason for the expectation was that most universities in Malaysia placed in a frame and hanged their vision and mission statements at all faculties and departments in the campus so that staff and students became fully aware of the university's aspiration and direction.

As for research question 2, Table 2 shows the results regarding the cultural differences between premier public and private institutions in Malaysia. As a note, the average mean is the average of all the means of scores of items of a particular domain.

Table 2

Average mean value and rank of cultural domains between premier public and private universities

\begin{tabular}{|c|c|c|c|c|}
\hline \multirow[t]{2}{*}{ Cultural Domain } & \multicolumn{2}{|c|}{ Premier public universities } & \multicolumn{2}{|c|}{ Premier private universities } \\
\hline & Average mean & Rank & Average mean & Rank \\
\hline Mission and vision for guide & 3.791 & 3 & 3.572 & 9 \\
\hline Goals and objectives to be achieved & 3.753 & 5 & 3.524 & 10 \\
\hline $\begin{array}{l}\text { Strategic direction and intent of } \\
\text { management }\end{array}$ & 3.674 & 10 & 3.596 & 7 \\
\hline Core values of university & 3.713 & 8 & 3.643 & 5 \\
\hline Agreement in decisions & 3.6547 & 11 & 3.511 & 11 \\
\hline Management Coordination & 3.615 & 12 & 3.473 & 13 \\
\hline Empowerment in programs & 3.817 & 2 & 3.652 & 4 \\
\hline Team orientation of people & 3.764 & 4 & 3.695 & 2 \\
\hline Capability enhancement of people & 3.753 & 6 & 3.673 & 3 \\
\hline Making innovations/ changes & 3.715 & 9 & 3.582 & 8 \\
\hline Attention to customer needs/ focus & 3.563 & 13 & 3.493 & 12 \\
\hline Vital university policies/ Reputation & 3.871 & 1 & 3.829 & 1 \\
\hline
\end{tabular}

Looking at the rank column in Table 2, the cultural domain regarding university reputation was ranked 1 for both public and private premier universities, but they differed in eleven other cultural domains. For example, empowerment domain was ranked 2 for premier public universities, but on the contrary it was ranked 4 for private universities. Team orientation domain, however, was ranked 2 in private universities, but was ranked 4 at public universities. Vison and mission domain was ranked 3 in public universities, but ranked 9 in private universities.

On the other hand, based on Table 2 also, results indicated that customer focus domain was ranked 13 in public universities, but ranked 12 in private universities. This result indicated that students in both types of universities were fairly satisfied with their universities in terms of fulfilling some customer needs. Also, the agreement and coordination domains were lowly ranked-rank 11, 12, and 13. Thus, apparently students had perceived that those domains were fairly lacking in the organization culture in both types of universities.

As for research question 2, an in-depth analysis was made to it by statistically testing this hypothesis: There are no significant differences in the cultural domains between premier public and private universities. The best statistics for testing this hypothesis was Levene's test for equality of variances-combining t-test results as well. From the analysis, the table of results typically has two rows: first row for variances assumed to be equal if probability $p<$ 0.05 significance level, while the second row for variances not assumed to be equal if $p>0.005$. (George \& Mallery, SPSS Version 23, 2016, Tutorials online). 


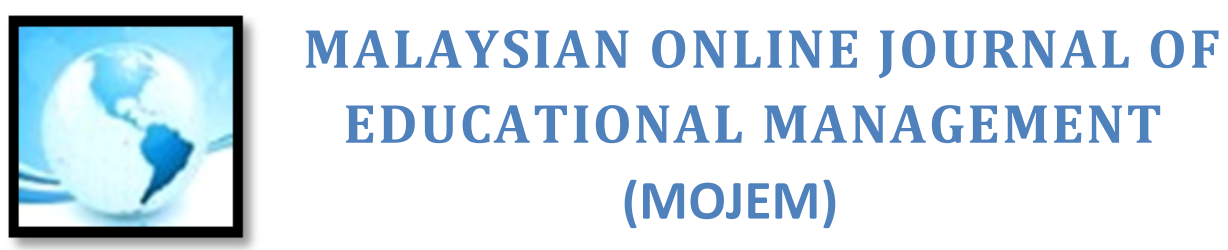

Table 3 below portrays the results of Levene's test analysis. As a note, the first row of results for every cultural domain indicates equality of variances assumed (EV assumed), while the second row of results indicates equality of variances not assumed (EV not assumed).

Table 3

Levene's test results: Values of variances F and t-test for determining significant differences of the cultural domains between premier public and private universities

\begin{tabular}{|c|c|c|c|c|c|c|c|}
\hline $\begin{array}{l}\text { Cultural } \\
\text { Domain }\end{array}$ & & $\mathrm{F}$ & Sig. & $\mathrm{T}$ & $\mathrm{df}$ & $\begin{array}{l}\text { Sig. (2- } \\
\text { tailed) }\end{array}$ & $\begin{array}{l}\text { Mean } \\
\text { Difference }\end{array}$ \\
\hline \multirow[t]{2}{*}{ Mission: Vision } & $\begin{array}{l}\text { EV } \\
\text { assumed }\end{array}$ & 1.808 & 0.179 & 7.889 & 1433 & 0.000 & 0.247 \\
\hline & $\begin{array}{l}\text { EV not } \\
\text { assumed }\end{array}$ & & & 7.889 & 1431 & 0.000 & 0.247 \\
\hline Mission: Goals \& & & 21.035 & 0.000 & 6.483 & 1433 & 0.000 & 0.223 \\
\hline Objectives & & & & 6.483 & 1410 & 0.000 & 0.223 \\
\hline Mission: Strategic & & 26.624 & 0.000 & 2.759 & 1433 & 0.006 & 0.081 \\
\hline Direction \& Intent & & & & 2.759 & 1369 & 0.006 & 0.081 \\
\hline Consistency: Core & & 46.029 & 0.000 & 2.914 & 1433 & 0.004 & 0.092 \\
\hline Values & & & & 2.914 & 1362 & 0.004 & 0.092 \\
\hline Consistency: & & 23.994 & 0.000 & 4.137 & 1433 & 0.000 & 0.143 \\
\hline Agreement & & & & 4.137 & 1407 & 0.000 & 0.143 \\
\hline Consistency: & & 8.969 & 0.003 & 3.145 & 1433 & 0.002 & 0.110 \\
\hline \multicolumn{7}{|l|}{ Integration } & 0.110 \\
\hline Involvement: & & 44.105 & 0.000 & 4.852 & 1434 & 0.000 & 0.172 \\
\hline Empowerment & & & & 4.853 & 1371 & 0.000 & 0.172 \\
\hline Involvement: & & 30.862 & 0.000 & 2.025 & 1434 & 0.043 & 0.072 \\
\hline Team Orientation & & & & 2.025 & 1393 & 0.043 & 0.072 \\
\hline Involvement: & & 21.057 & 0.000 & 1.425 & 1434 & 0.155 & 0.047 \\
\hline Capability & & & & 1.425 & 1406 & 0.155 & 0.047 \\
\hline \multicolumn{8}{|l|}{ Development } \\
\hline Adaptability: & & 5.486 & 0.017 & 3.518 & 1434 & 0.000 & 0.129 \\
\hline Creating Change & & & & 3.518 & 1433 & 0.000 & 0.127 \\
\hline Adaptability: & & 10.490 & 0.001 & 2.091 & 1433 & 0.038 & 0.076 \\
\hline Customer Focus & & & & 2.091 & 1413 & 0.038 & 0.076 \\
\hline Adaptability: & & 23.494 & 0.000 & 3.211 & 1433 & 0.001 & 0.115 \\
\hline $\begin{array}{l}\text { Organizational } \\
\text { Learning }\end{array}$ & & & & 3.211 & 1394 & 0.001 & 0.115 \\
\hline Important & & 13.869 & 0.000 & 1.054 & 1433 & 0.294 & 0.038 \\
\hline $\begin{array}{l}\text { Policies / } \\
\text { Institutional } \\
\text { Reputation }\end{array}$ & & & & 1.054 & 1422.77 & 0.294 & 0.038 \\
\hline Overall Mean & & 30.036 & 0.000 & 4.438 & 1435 & 0.000 & 0.117 \\
\hline & & & & 4.437 & 1398 & 0.000 & 0.117 \\
\hline
\end{tabular}

Reading Table 3, we could conclude that there were significant differences between premier public and private universities in all the domains of organizational culture. All domains, except the mission domain, have variances assumed to be equal (i.e. $p<0.05$, hence reading results in the second row of each domain). Thus, we concluded that premier public universities had a totally different organizational culture from the premier private universities. 


\section{MALAYSIAN ONLINE JOURNAL OF EDUCATIONAL MANAGEMENT (MOJEM)}

\section{DISCUSSION}

Unlike many previous research works in the university organizational culture area that have used McNay's CVF model (1995), our research is thus not the common typology type. It has employed Denison's (1990) model which examined deeply the specific elements in each of the thirteen domains of university organization. This is a step forward, and we hope many more similar kind of studies will be conducted in the future. Qualitative studies can also be done using Denison's model, with elements, domains, and components that can serve as guiding codes, concepts, and sub-themes respectively.

The findings of this research have somewhat verified the tenability of the open system theory, which posits that there is a dynamic interaction between external and internal forces in shaping university organizational culture (Weber \& Waeger, 2017; Yacizi \& Karabag, 2019). In other words, the premier universities in our study were internally responsive strategically to external forces such as international trends and developments, and henceforth the dynamic interaction of forces could be viewed as a way an open system makes adjustments or innovations to achieve an equilibrium. This fact is exemplified by the intermingling of four cultural componentstwo components namely mission and consistency constitute the external forces, whereas the other two components namely involvement and adaptability constitute the internal forces. For example, this study found that the crucial cultural domains were important university policies regarding reputation, core values, team orientation of staff and students; empowerment of staff and students, capability development of staff and students. In this case, the former two domains were the external forces and the latter three domains were the internal forces. Furthermore, the interplay of external and internal forces can be seen at the lowest-ranked domains such as customer focus, coordination and integration among faculties and departments, and agreement among faculties in decision-making process. In this case, customer focus was the internal force, whereas the other domains were the external forces.

In synthesis, the argument before theoretically implies that the organizational culture of premier public and private universities concentrates more on internal focus than on external focus, and also more on flexibility in making changes and innovations than on rigidity in consistency of status quo, bureaucratic implementation of mission and vision, and adherence to long-held core values (Köse \& Korkmaz, 2019). The argument also portrays that university development should encompass all components and domains organizational culture, not selective either on internal components only or external ones only. Premier universities or the newly established universities should not have a dichotomous development plan, otherwise they would have one-sided development or they would not have the competitive advantage in many aspects (Clark, 1986; O'Dell, 2014). Managerialism must be balanced with academic empowerment and capability development via design thinking and systems thinking (Kramer \& Berman, 2009; Senge, 1990). It has been argued that overwhelming managerialism in university management could create profound dissatisfaction, tension, barriers, and conflicts (White, Carvalho, \& Riordan, 2011).

\section{IMPLICATIONS}

The findings of this study have a few implications. Firstly, policies related to a university's reputation should be spelled out clearly and disseminated in many ways so as to ensure that the entire university community is consciously aware of upholding the reputation when exercising their duties and responsibilities (Hussin \& Wong, 2015). For example, academic merit, academic integrity and originality of research works are always the ethics related to reputation. A tarnished reputation is difficult to amend locally and internationally and this could affect networking and student enrolment. Secondly, academic empowerment and autonomy are not a foregone liberal tradition in higher learning institutions because those two concepts are needed for research and knowledge advancement and for triggering innovative programs by staff and students (Černe, Jaklič, Škerlavaj, Aydinlik, \& Polat, 2012; Naranjo-Valencia, Jiménez-Jiménez, \& Sanz-Valle, 2011; Naranjo-Valencia, Sanz-Valle, \& Jiménez, 2010). Universities are not bureaucratic organizations. Thirdly, vision and mission statements of a university should 


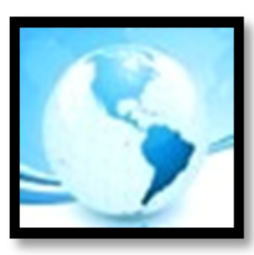

\section{MALAYSIAN ONLINE JOURNAL OF EDUCATIONAL MANAGEMENT (MOJEM)}

be inspiring and motivational and they should be made easily accessible for easy reference of staff, students, and other people (Ozdem, 2011). Furthermore, vision and mission statements should be achievable and measurable for the purpose of assessment of job performance. And fourthly, new colleges and universities can make use of the results and findings of this research as benchmarks in their pursuit to be world-ranked universities.

\section{CONCLUSION}

Universities are an open system, meaning that they are susceptible to the internal cultural elements as well the external cultural elements of the larger society, and the interplay of all cultural elements makes universities to be complex organizations. Rationality can only derived from a systematic analysis of concepts or variables involved, and the use of models could facilitate research process. There are two major theoretical models available to study quantitatively the organizational culture of universities, such as the CVF model and Denison's model.

Using Denison's model, this research has determined the important domains of university culture such as university policies related to reputation, teamwork orientation, academic empowerment, university mission, and capability development in the culture of some premier universities in Malaysia. The research has also determined that the cultural domains of premier public universities are significantly different from that of the premier private universities. It is recommended that similar studies involving more universities and a bigger sample should be conducted to affirm or repudiate the findings of this study and theories used.

\section{REFERENCES}

Asimiran, S. (2009). Governance of public universities in Malaysia. (Unpublished Doctoral Thesis). Faculty of Education, University of Malaya.

Asimiran, S., \& Hussin, S. (2012). University governance: Trends and models. Kuala Lumpur: University of Malaya Press.

Beytekin, O. F., Yalçinkaya, M., Doğan, M., \& Karakoç, N. (2010). The organizational culture at the university. International Journal of Educational Researchers, 1(2), 1-13.

Černe, M., Jaklič, M., Škerlavaj, M., Aydinlik, A. Ü., \& Polat, D. D. (2012). Organizational learning culture and innovativeness in Turkish firms. Journal of Management \& Organization, 18(2), 193-219.

Creswell, J. (2012). Educational assessment: Planning, conducting, and evaluating quantitative and qualitative research. Boston, MA: Pearson.

Clark, B. R. (1986). The higher education system: Academic organization in cross-national perspective. Berkeley: University of California Press.

Denison, D. R. (2020). Organizational culture surveys. Retrieved from https://www.denisonconsulting.com/culturesurveys/

Denison, D. R. (1990). Corporate culture and organizational effectiveness. New York: John Wiley \& Sons.

Gaus, N., Tang, M., \& Akil, M. (2017). Organizational culture in higher education: mapping the way to understanding cultural research. Journal of Further and Higher Education, 43(6), 848-860. doi: 10.1080/0309877X.2017.1410530

George, D., \& Mallery, P. (2016). IBM SPSS Statistics 23 step-by-step: A simple guide and reference (14 ${ }^{\text {th }}$ Ed,). New York: Routledge. Online tutorials retrieved at https://libguides.library.kent.edu/SPSS/Independent t-test .

Gibson, D. E., \& Barsade, S. (2003). Managing organizational culture change. Journal of Social Work in Long-Term Care 2(1-2), 11-34. doi: 10.1300/J181v02n01_02,

Gornitzka, A., \& Maasen, P. (1998). Theoretical framework. TSER/HEINE Project Enschede. Netherlands, CHEPS.

Gornitzka, Å., \& Peter, M. P. (2000). Hybrid steering approaches with respect to European higher education. Higher Education Policy, 13(3), 267-285. doi: 10.1016/S0952-8733(00)00012-X.

Hair, J. F., Black, W. C., Babin, B. J., \& Anderson, R. E. (2006). Multivariate Data Analysis: A global perspective. New Jersey: Prentice Hall, Pearson Education. 


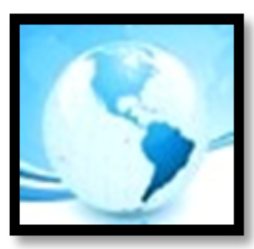

Hofstede, G. H., \& Hofstede, G. (2001). Culture's consequences: Comparing values, behaviors, institutions and organizations across nations. San Francisco: Sage.

Hussin, S., \& Wong, S. C. (2011, 4-6 July). Organizational citizenship behavior in universities: incorporating autonomy and empowerment into a correlationship. Paper presented at IATED Conference, Barcelona, Spain.

Hussin, S., \& Wong, S. C. (2015). Empowerment of University Academics: Its aspects and extent. Published conference paper at $7^{\text {th }}$ International Conference on Education and Learning Technologies, EDULEARN 15, Barcelona, Spain, 6-8 July 2015. ISI -Conference Paper Index. Paper number 180.

Ismail, A. (2008). Information technology governance, funding and structure: A case analysis of a public university in Malaysia. Campus-Wide Information Systems, 25(3), 145-160.

Jameson, J. (2011). Distributed leadership and the visibility/invisibility paradox in on-line communities. Human Technology: An Interdisciplinary Journal on Humans in ICT Environments, 7(1), 49-71.

Köse, M. F., \& Korkmaz, M. (2019). Why are some universities better? An evaluation in terms of organizational culture and academic performance. Higher Education Research and Development, 38(2), 1-14.

Kramer, M. W., \& Berman, J. E. (2009). Making sense of a university's culture: An examination of undergraduate students' stories. Southern Communication Journal, 66(4), 297-311.

Krejcie, R. V., \& Morgan, D. W. (1970). Determining sample size for research activities. Educational and Psychological Measurement, 30(3), 607-610.

McNay, I. (1995). Universities going international: choices, cautions and conditions. Policy and policy implementation in internationalization in higher education. Amsterdam: EAIE.

Naranjo-Valencia, J. C., Sanz Valle, R., \& Jiménez, D. (2010). Organizational culture as determinant of product innovation. European Journal of Innovation Management, 13(4), 466-480.

Naranjo-Valencia, J. C., Jiménez-Jiménez, D., \& Sanz-Valle, R. (2011). Innovation or imitation? The role of organizational culture. Management Decision, 49(1), 55-72.

O'Dell, J. B. (2014). The relationship between the leadership practices of presidents and the organizational culture of Christian colleges and universities. Journal of Applied Christian Leadership, 8(2), 112.

Ozdem, G. (2011). An analysis of the mission and vision statements on the strategic plans of higher education institutions. Educational Sciences: Theory \& Practice, 11(4), 1887-1894. Retrieved from https://files.eric.ed.gov/fulltext/EJ962679.pdf.

QS World Ranking of Universities. (2017). QS World University Rankings by Subject. Retrieved from https://www.topuniversities.com/subject-rankings/2017

Schein, E. H. (1985). Organizational culture and leadership. San Francisco: Jossey-Bass.

Schein, E. (2004). Organizational culture and leadership. San Francisco: John Willey \& Sons.

Senge, P. (1990). The Fifth Discipline. The Art and Practice of the Learning Organization. New York: Doubleday.

Sporn, B. (1996). Managing university culture: an analysis of the relationship between institutional culture and management approaches. Higher Education, 32(1), 41-61.

Tama, K. M. (2019). Organizational culture mapping analysis through Organizational Culture Assessment (OCA). Masyarakat, Kebudayaan dan Politik, 32(2), 186-195.

Wang, L. S. (2016). What is culture of college/school/department. US-China Education Review B, 6(3), 151-156. doi: 10.17265/2161-6248/2016.03.002

Weber, K., \& Waeger, D. (2017). Organizations as polities: An open systems perspective. The Academy of Management Annals, 11(2), 886-918. doi: 10.5465/annals.2015.0152, Retrieved from https://www.researchgate.net/publication/314152232_Organizations_As_Polities_An_Open_Systems_Pe rspective.

White, K., Carvalho, T., \& Riordan, S. (2011). Gender, power and managerialism in universities. Journal of Higher Education Policy and Management, 33(2), 179-188.

Wright, M. V. (2019). The university as a public good. In C. D. Wan, M. Sirat, \& D. A. Razak (Eds.), Higher education in Malaysia: A critical review of the past and present for the future. Penang: University of Science Publisher. 


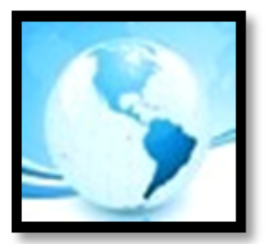

\section{MALAYSIAN ONLINE JOURNAL OF EDUCATIONAL MANAGEMENT \\ (MOJEM)}

Yacizi, S., \& Karabag, A. (2019, November 18). Organizational culture, learning organization, and innovation in German higher education institutions. Paper presented at IACCM Conference. 